\title{
The Garrison Shops for the Security Sector in Zimbabwe: Financing Mechanisms and Military Budgets
}

\author{
Lovemore Mwale', Gorden Moyo² \\ ${ }^{1}$ Masters in Public Policy and Development Management Degree, Lupane State University, Bulawayo, Zimbabwe \\ ${ }^{2}$ Faculty of Social Sciences and Humanities, Lupane State University, Bulawayo, Zimbabwe \\ Email: lovemoremwale3@gmail.com
}

How to cite this paper: Mwale, L., \& Moyo, G. (2021). The Garrison Shops for the Security Sector in Zimbabwe: Financing Mechanisms and Military Budgets. iBusiness, 13, 67-79.

https://doi.org/10.4236/ib.2021.131005

Received: September 21, 2020

Accepted: March 28, 2021

Published: March 31, 2021

Copyright () 2021 by author(s) and Scientific Research Publishing Inc. This work is licensed under the Creative Commons Attribution International License (CC BY 4.0).

http://creativecommons.org/licenses/by/4.0/

\section{(c) (i) Open Access}

\begin{abstract}
This think piece discusses the proposed policy on garrison shops designed for the members of the Zimbabwe Defence Forces to purchase subsidised groceries in their barracks, camps and cantonments. In mulling this policy intervention, the ruling executive-military alliance led by President Emmerson Mnangagwa was responding to the dire economic and social problems faced by the ordinary soldiers and police officers. It is common cause that the country is currently going through an economic recession that is adversely impacting on the ordinary Zimbabweans and the ordinary soldiers and police officers have not been spared. Notably, compared to their bosses, the rank and file officers' incomes are far below the poverty datum line. The article, therefore, sets out to discuss the drivers, financing mechanisms and military budgets so as to locate the efficacy of the proposed garrison shops in the Government of Zimbabwe's efforts to alleviate the plight of the security services sector. It concludes by gesturing towards the future of targeted, purposive, quantified and budgeted subsidies which benefit the poor, vulnerable and well-deserving cases against the current rent seeking subsidies in the security sector in Zimbabwe.
\end{abstract}

\section{Keywords}

Financing Mechanism, Garrison Shops, Military Expenditures, COVID-19, Zimbabwe

\section{Introduction}

This article discusses the policy of garrison shops meant for the members of the security sector to purchase subsidised groceries in their barracks, cantonments, 
and camps to cushion them from the rising cost of living in Zimbabwe. It is a matter of public truth that Zimbabwe is currently experiencing economic contractions that are fuelling increase in prices of basic commodities with adverse impact on the ordinary Zimbabweans, the ordinary soldiers and police officers have not been an exception. In response, on 28 February 2020, the ruling executive-military alliance led by President Emmerson Mnangagwa announced its intention to re-establish garrison shops for the members of the security sector after they had been moribund for over a decade (Mabhiza, 2020; Mugabe, 2020; Saungweme, 2020a).

It is almost trite to say that Zimbabwe's economy is woeful. Its problems are legion. To be clear, Zimbabwe's economy is characterized by high levels of unemployment, poverty, hyperinflation, a non-existent private sector, a ransacked treasury, hopelessly uncompetitive manufacturing, and crumbling infrastructure as well as a crisis of cash, food, water and power shortages among others (Trading Economics, 2020). Currently, the members of the state security services who earn a gross salary below the poverty datum line (ZWL9000 at the time of writing) while other civil servants like teachers are getting ZWL3500, have been struggling to eke a living (Kells, 2020; Matenga, 2020). This situation has been further worsened by the eruption of the coronavirus aka COVID-19 pandemic which has deepened the economic headwinds and upended the welfare of millions of people (Moyo, 2020a).

Against this backdrop, they have been reports that top officers in the military and the intelligence sector are worried about a possible security crisis from the underpaid and hungry soldiers who feel betrayed despite having been instrumental in ushering in the Mnangagwa administration. It is worth noting here that the military plays a vital role in installing Emmerson Mnangagwa as the President of Zimbabwe in November 2017 after ousting the long serving and ailing former President Robert Mugabe. As such, the military is a key stakeholder in the Mnangagwa administration (Moyo \& Phulu, in press). And yet, the ordinary soldiers and police officers live in penury in Zimbabwe. Some observers note that if the situation of the military officers is not properly addressed, riots would set in and send the government system into a crisis with the possibility of an armed insurrection in the country (Mugabe, 2020). This think piece therefore sets out to discuss the drivers, financing mechanisms and military budgets so as to locate the efficacy of the policy proposed on garrison shops as a policy response to the deepening plight of the members of the security sector in Zimbabwe.

The data used in this article was collected through key informant interviews from some members of the security forces, policy makers, members of parliament, civil society and academics. The informants were purposively selected. In light of the COVID-19 pandemic restrictions, the researchers deployed digital technologies to collect data including emails, telephone interviews, and virtual meetings though some informants were sensitive to the use of their identities. 
The rest of the article is structured as follows: Section 2 provides the contextual and conceptual contours of the paper; Section 3 discusses drivers and motives for the garrison shops policy; Section 4 addresses the financing of the policy; Sections 5, 6, and 7 discuss military expenditures, implications and recommendations respectively; while Section 8 concludes the discussion.

\section{Contextual and Conceptual Issues}

It is instructive to note that over the past few years Zimbabwe's economy has been a subject of the world's surveillance not for an outstanding performance, but rather for its appalling performance. Recent statistics indicate that the country's fiscal deficit stood at around 4.9 percent of gross domestic product (GDP) in 2019 with a gradual decrease to 4.5 percent and 4.4 percent of GDP in 2020 and 2021 respectively (World Bank, 2019). At the same time, the number of extremely poor was estimated to rise to 5.7 million as of 2019 up from 4.7 million the previous year. In addition, at the time of writing this paper, 8.5 million people were food insecure in a population of 16 million, and the sovereign debt burden stood at over US\$20 billion as of February 2020 (Moyo, 2020a; Zimbabwe National Statistics Agency, 2020).

As previously mentioned, the civil service as well as the members of the security sector who earn a gross salary below the poverty datum line are among the most severely affected by the harsh economic climate as they are unable to access the basic commodities needed to sustain life. Paradoxically, the military has been acquiring, from Beijing and Kremlin, sophisticated equipment including items needed for new command, control, communication, and intelligence systems while the rank and file soldiers and police officers are living in penury (Rupiya, 2005; Moyo, 2016, 2019). The tension between huge military expenditures against underpaid members of the armed forces is a contradiction that deserves scholarly attention. On the short-term, government has proposed to respond to the welfare plight of the members of the security sector by way of setting up garrison shops.

By definition, garrison shops are subsidized shops set up within military and police camps and barracks by government for the exclusive benefit of the members of the security forces and their families to mitigate the constantly rising cost of living. For the purposes of this discussion a subsidy is defined as a financial contribution by a government, or agent of a government, that confers a benefit on its recipients (Leach, 2004). In other words, subsidies comprise all measures that keep prices for consumers below the market level or keep prices for producers above the market level or that reduce costs for consumers and producers by giving direct or indirect support. Viewed from this perspective, garrison shops provide discounted groceries especially basic commodities and household goods. Globally, the beneficiaries of this kind of arrangement consist of serving members of the security forces as well as retired members and their immediate families. This arrangement is intended to become part of the conditions of ser- 
vice for the security personnel and also to restrict movement of troops outside cantonments and avoid social mingling with the public.

As such, the governments the world over establish garrisons shops to ensure the convenient access to goods and services at reasonable prices by the service men and women. The United States of America has the best known on-base department stores and on-base grocery stores. This practice has also been borrowed by other administrations in the trans Atlantic ream including the Germany, France and the UK. In Africa, the practice has been witnessed in countries which came as a result of military coups for example Sudan, Democratic Republic of Congo (DRC), Gambia and recently Zimbabwe where garrison shops concept have become part of the ecology of the uniformed forces (Dwyer, 2016). The practice has been somewhat different in the African context in that it has been disguised as a reward model were cheap loans, accommodation, subsidized commodities and education opportunities are provided for the role played by the army in military coups (Dwyer, 2017; Darboe, 2010). Accordingly, in most cases access to such shops and stores is part of the conditions of services for service personnel and the primary intent is to maintain the high morale of the armed forces.

It is worth noting from the outset that Zimbabwe's military barracks, cantonments, and camps have always had canteens and garrison shops. Thus, the garrison shops' physical structures already exist in these shops where they sell basic commodities and including beer. As noted earlier, these shops were established mainly to ensure the convenient access by service personnel to reasonably priced commodities and limit traffic of service personnel having to leave barracks in search of food supplies and groceries. However, against the backdrop of the ongoing economic recession, fiscal sustainability problem and lack of resources, most of these shops are not well stocked and therefore not as functional as originally intended hence the new proposal to re-establish these garrison shops.

It is important to recall that traditionally, garrison shops have operated in Zimbabwe as food pantries and food banks for soldiers in barracks, cantonments, and camps. To be sure, a food bank is a place where perishable and non-perishable food items are stocked with the intention to provide them to officers under training in barracks (Mugabe, 2020). Thus, garrison shops or food banks were meant for privates or soldiers under training who would be allowed to obtain basic commodities on credit. Payment would be made after a couple of months following their remuneration in an arrangement which sufficed only when the economy was still stable. With time garrison shops diversified to include household goods such as refrigerators, television sets, radios, and furniture, to ease the burden of going out of barracks for soldiers who would be occupied, in most cases with their assignments.

It is evident that, following the economic meltdown and rising inflation in the early 2000s, sustaining the garrison shops became virtually impossible. To restock from money paid back months later and in most cases eroded by rising in- 
flation was not sustainable. Viewed from this perspective, the re-establishment of garrison shops aims at cushioning the members of the military from rising year on year inflation which at the time of putting together this article stood at 786 percent and from exorbitant prices of basic commodities which have continued to increase (Trading Economics, 2020).

\section{Motives and Drivers of the Policy on Garrision Shops}

Broadly speaking, public policy in Zimbabwe is currently driven by the ruling executive-military oligarchy led by President Mnangagwa which took over power through a coup de tat in November 2017. The current government is dominated by the former military generals including the former Commander of the Defence Forces Constantino Chiwenga and the coup-announcer General Sibusiso Moyo who is now the Minister of Foreign Affairs among others (Moyo \& Phulu, in press). Alieu Darboe in his article titled "The Gambia: 1994-Present," called it the executive-military alliance were fired but loyal generals would be assigned to ministerial jobs or ambassador positions (Darboe, 2010). In this context, there is a symbiotic relationship between the politicians and the military officials. Arguably, the civilian leaders provide opportunities for senior army officials to increase their wealth as a reward for their loyalty in ensuring the stability of the ruling Zimbabwe African National Union-Patriotic Front (ZANU PF) government. In his seminal article on "The Curse of Military Commercialism in State Enterprises and Parastatals in Zimbabwe", Gorden Moyo explains how the military officials spend part of their time accumulating wealth for political patronage and to ensure the stability and strong power of the government (Moyo, 2016). This situation has intensified since the November 2017 coup as the senior military officials have become a core element of the state-party-military alliance that constitutes the Zimbabwean regime.

It is the argument of this think piece that both top officials in the military and the political leaders want to maximise their vested interests, where political leaders want regime stability and the military officials want personal gains without sacrificing their status within the military hierarchy. However, one of the puzzling questions facing many scholars of public policy especially those engaged in military commercialism studies is how to comprehend and interpret the problems faced by the rank and file soldiers and police officers in Zimbabwe at a time when the security sector has a bigger claim in the economic affairs of the state. As previously implied, the military has its footprint in the major sectors of the economy including mining, agriculture, and manufacturing, construction, and telecommunications subsectors, yet the ordinary soldiers are lowly remunerated, their uniforms are in a sorry state, and their children are struggling with school fees (Moyo, 2016). Perhaps it is the greed of the military officials or perhaps the military companies that all Zimbabwe and businesses are struggling. A more nuanced discussion on these and other related questions falls outside the scope of this think piece, serve to note that there is need for a policy 
response to the plight of the ordinary soldiers and police officers and their families.

As explained, the members of the state security services who earn a gross salary below the poverty datum line have not been spared from the harsh economic climate making them unable to afford the basic commodities needed to sustain life. Added to the problem of low salaries and inadequate food supplies is the problem of uniforms. As a matter of convention government should provides four sets of uniforms per member of the security sector but as at the time of writing this article, most members had only one uniform such that any average person could identify Zimbabwean soldiers and police officers by their worn-out uniforms and boots (Mugabe, 2020).

The plight of the armed forces has forced some of them to dissert the army or to indulge in petty crime, and armed robbery. At the height of insufficient food in the barracks some military officers engaged in criminal activities like robberies to support their families. For example, security forces have been forcibly collecting subsidized food stuffs from food depots while others are reported to have blocked people from accessing essential services such as bank withdrawals in order to purchase basic commodities during the COVID-19 lockdown, while those who questioned them were beaten (Vinga, 2020). In 2019 a commander of One Commando regiment in Harare was arrested for allegedly stealing army rations valued at more than $\$ 500,000$ (Mugabe, 2020).

Again in July 2020, 10 serving soldiers holding the ranks of corporal and colour sergeant were arrested for robbing at gunpoint, Chidamoyo hospital in Hurungwe and got away with US $\$ 1700$ plus ZW $\$ 3000$ although they were later detained in Chinhoyi (Vinga, 2020). An interview with a general officer as a key informant at Tongogara Barrack revealed that there was serious discontent among military personnel over the rising cost of living emanating from an increase in food prices quickly eroding their salaries most of which was below the poverty datum line (ZIMSTAT, 2019). Thus, in a desperate bid to pre-empt mutiny over growing inadequate food supplies and low salaries the government had to revive the concept of the garrison shops (Mugabe, 2020).

Table 1 below provides a snapshot of the prices of the basic goods in ordinary shops compared to a few garrison shops that are now operating.

Table 1. Price comparison between garrison and regular shops.

\begin{tabular}{ccc}
\hline Item & Ordinary Shop Price & Subsidized Prices \\
\hline Flour 2 kg & ZWL\$150 & ZWL\$114 \\
Meat & ZWL $\$ 360$ & ZWL\$300 \\
Mealie Meal & ZWL\$480 & ZWL\$70 \\
Sugar 2 kg & ZWL\$215 & ZWL185 \\
Bally House Juice 2 litres & ZWL\$149 & ZWL\$128 \\
Cooking Oil 2 litres & ZWL\$280 & ZWL\$236 \\
Red Seal Rice & ZWL $\$ 210$ & ZWL\$169 \\
Boom Washing powder 2 kg & ZWL\$400 & ZWL\$346 \\
\hline
\end{tabular}

Compiled Authors. 
Table 1 above was drawn in August 2020, given the rate of inflation in the country; the listed prices are likely to have drastically changed. However, what is clear is that the garrison shops are purposed to ease the burden for security forces in purchasing basic commodities in barracks in order to address the challenges of inadequate food supplies in the face of serious economic down turn. As mentioned earlier, there were fears of possible riots by soldiers who have been subjected not only to poor working conditions in barracks with some on forced leave, but also due to rising inflation which has made them susceptible to inadequate food supply. The economic and social plight of the ordinary members of the uniformed forces has been exacerbated by the eruption of COVID-19 pandemic. It is therefore hardly surprising government was quick to release packages to members of the police and army which were six times more than other civil servants as part of their COVID-19 allowance ahead of the proposed national protest scheduled for July 31, 2020 (Ndebele, 2020). When teachers walked away with only ZWL1200, a 50 percent salary hike was set aside for the police and soldiers who confirmed reception of ZWL\$8000, while waiting for a non-taxable US\$75 three months COVID-19 allowance meant to cushion them from the economic crisis that had eroded earnings and savings (Kells, 2020).

Prior, to the said national protests, there were numerous reports that top officers in the military and the intelligence sector were worried about a possibility of a security crisis from hungry soldiers who felt betrayed at the economic suffering they were going through despite having been instrumental in the removal of former President Robert Mugabe in the November 2017 military coup (Mugabe, 2020). Therefore, government is under-pressure to find the money to pay for the garrison shop subsidies and this may have to come from taxation or borrowing, causing macroeconomic problems, or, at the very least, diverting money from socially valuable uses such as health and education. The following section is devoted to the issues of financing.

\section{Financing Mechanisms and Military Budgets}

The funding of the proposed garrison shops has been associated with so much confusion and skepticism. The initial plan of government was to finance them through imposing a 2.5 percent tax on civil servants. This meant that nurses, teachers and other state workers in the civil service were going to incur additional tax in order to finance the scheme. Not surprisingly, this was met with discontent and antagonism from representative bodies and unions of teachers, nurses and other state employees. A key informant interviewed for this article noted that the imposition of 2.5 percent was going to be grossly unfair, unjust and diabolic to the civil servants whose salaries and wages have become unsustainable in light of the runaway inflation in the country. Some workers unions called for stay-away and protest against government's move to add a new tax following another 2 percent Intermediated Money Transfer Tax (IMTT) imposed on the transacting public in 2018 (Moyo, 2020b).

Following, the heavy criticism of the proposed 2.5 percent tax, the Minister of 
Finance and Economic Development capitulated and announced that the garrison shops will adopt a self-financing model which entails government coming up with alternative ways of subsidizing the low prices of garrison shops (Saungweme, 2020b). To date, government has not explained the details of the revised financing mechanism for the proposed garrison shops. However, as explained, a general and contrary policy statement was made to the fact that the garrison shops will be a self-financing project which would operate just like regular shops and survive on profits generated from selling basic commodities and other essential goods. It remains to be seen how these shops will be subsidized and operate and how different will they be from the earlier version of garrison shops that collapsed under the weight of economic recession a decade ago.

What is of concern to scholars and researchers is that the security sector in Zimbabwe normally receives a reasonable budget which when properly and transparently allocated should be able to provide for the welfare of the general members of the uniformed forces. Nevertheless, while the military budget is a matter of public record, the military has remained largely secretive about the actual break down of expenditures which makes it difficult to ascertain the efficacy of resource distribution in the security services sector. A key informant interviewed for this article lamented over the level of secrecy associated with the influential military in the country where even legislators were clueless of the military budget structure. Neither parliament nor the public is informed in any detail about how the defence budget breaks down.

However, the veil on Zimbabwe's military expenditure, which has been shrouded in secrecy for decades, was lifted when the Stockholm International Peace Research Institute (SIPRI) Report, a security think-tank, revealed that the country spent US\$92 million between 2000 and 2006 and a total of US\$647 million since independence in 1980 for the acquisition of military hardware (Kairiza, 2020). According to the SIPRI Report titled, (Transfer of Major Weapons: Deals with Deliveries or Orders Made From 1995 to 2019), the ruling executive-alliance led by Mnangagwa shelled out millions of dollars on the procurement and refurbishment of armaments through undeclared and opaque transactions to Asia and Eastern Europe at a time of unprecedented economic upheaval in the country (Kairiza, 2020).

Moreover, like its predecessor, the Mnangagwa government has also displayed profligacy, particularly by splashing vast amounts of money on the procurement of armaments and the appeasement of military chiefs. As reported in the press, Zimbabwe Defense Forces acquired an assortment of weapons, including AK assault rifles, millions of pieces of ammunition, 5000 mortar bombs and 58,500 grenades (Kairiza, 2020). Table 2 below provides some information on arms delivery to Zimbabwe Defense Forces and the relevant costs.

As shown in Table 2 below, the military hierarchy in Zimbabwe prioritizes hardware such as AK assault rifles, rounds of ammunition, mortar bombs as well as tankers and other military vehicles at a time when the country is not at war neither is it facing any external threats. Moreover, military leaders often 
Table 2. Arms delivery and relevant cost to Zimbabwe.

\begin{tabular}{|c|c|c|c|}
\hline Military Equipment & Year & $\begin{array}{l}\text { Supplying } \\
\text { Country }\end{array}$ & Cost \\
\hline 60 Units M43 (120 mm) Mortar & 1999 & Bulgaria & US\$1 million \\
\hline $\begin{array}{l}6 \text { Units self-propelling } \\
\text { Stalin Organ RM-70 }(122 \mathrm{~mm})\end{array}$ & 2000 & Slovakia & US\$1 million \\
\hline $6 \mathrm{MI}-24 \mathrm{P}$ combat helicopter gunship & 2000 & Russia & US\$22 million \\
\hline Mig fighter jets & 2000 & Russia & $\begin{array}{l}\text { Joint platinum mining } \\
\text { deal worth US } \$ 3 \text { billion }\end{array}$ \\
\hline $3 \mathrm{Mig}-230 \mathrm{M}$ aircraft & 2003 & Libya & US $\$ 15$ million \\
\hline $\begin{array}{l}10 \text { Units } 85 \text { IVS, } 5 \text { Units } 89 / Z S D \\
\text { armoured carriers \& } \\
6 \mathrm{~K}-8 \text { Karatorum jet trainer aircraft }\end{array}$ & 2004 & China & US $\$ 55$ million \\
\hline $6 \mathrm{~K}-8$ Karatorum trainer aircraft & 2006 & China & US\$21 million \\
\hline $\begin{array}{l}12 \text { Units AL-25 turbofan engines } \\
\text { for Karakorum aircraft }\end{array}$ & $2001-2006$ & Ukraine & US\$17 million \\
\hline $\begin{array}{l}\text { Refurbishment of EE9 } \\
\text { armoured vehicles (Cascavels) }\end{array}$ & 2014 & Dubai & - \\
\hline
\end{tabular}

Source: Kairiza (2020).

manipulate tenders for personal gain. The tenders for even routine items like uniforms and food are often severely manipulated and usually awarded to companies which are non competitive in order to create payoffs for military officials (Moyo, 2016). Apparently the opportunity cost of the rising military spending is seen in the reduced spending elsewhere in the economy, such as education, health and welfare subsidies, among others and this has knock on consequences for human capital formation and further strains the society-military relations. Government's commitment towards increasing military hardware while ignoring welfare of ordinary members of the security forces is a cause-for-concern.

In addition to the above expenditures, press reports also indicate that brigadier generals were given Toyota Land Cruisers and those who were retiring at the age of sixty were given the option to buy their old vehicles at a book price (Mabhiza, 2020). To be clear, prices for the Toyota Hilux Workmate and Toyota Hilux Rugged X $(4 \times 4)$ at that time ranged between US $\$ 18,447$ and US\$62,950, respectively. Toyota Land Cruiser vehicles meant for brigadier-general costs about US\$85,000 (Mabhiza, 2020). Old vehicles were apparently going to be sold to those retiring for $\mathrm{ZW} \$ 500$, equivalent to less than US\$10 (Mabhiza, 2020). Moreover, when disposing of vehicles, transparency and accountability loose ends have remained rampant with vehicles given away at a token price. All these are benefits enjoyed by the military bosses at a time when the rank and file soldiers are struggling to survive. It is therefore the argument of this article that greed, corruption and political expediency are major contributors to the plight of the ordinary soldiers and police officers. 


\section{Gesturing the Future}

Arguably, the general citizenry in Zimbabwe has had a negative perception towards both the security establishment and the garrison shops which to them are nothing but patronage project. In fact, many Zimbabweans lamented the selective approach of the government in proposing to subsidize basic commodities in garrison shops only for the benefit of the members of the armed forces at a time when those in the civil service were finding it difficult to eke a living. As such, the motive military subsidies have been viewed as having an element of corruption since the benefit is not spread to all deserving citizens.

Although corruption appears relatively common across numerous institutional domains in Zimbabwe, it is concerning in the military sector which is secretive about its expenditures as explained. It is instructive to note that the Auditor General's report of 2019 revealed that there was massive corruption in the public sector including the Zimbabwe Defence Forces. Regarding the Zimbabwe Defence Forces (ZDF), the Ministry of Defense was one of the stations which were not visited which makes it difficult to obtain sufficient audit evidence (Auditor General Report, 2018). Going forward there is a need to improve the public finance management of the military budget which should be subject to audit by the Auditor General (Auditor General Report, 2018). Government can ill afford to keep wasting much of state resources, as has been documented by a large body of performance audits, investigative journalism, academic findings, and non-profit research.

One way to combat corruption is to ensure greater transparency in military expenditure. Although this action may be perceived as jeopardising national security, it is in the public interest to find an optimal level of transparency that will not affect national security (Ali \& Solarin, 2019). Sadly, civil society organisations seeking to improve transparency and rule of law have been systematically persecuted and impeded in their work under the Mnangagwa government. It is therefore critical for Zimbabwe to undertake reform institutions that relate to supervision, management and control over the security sector so that the relevant institutions from this sector would function in accordance with the constitution. Specifically, this supposes:

- Reforming and professionalization of ministries responsible for the security services and strengthening of the legislative supervision over their functions as well as enabling auditing of defense budgets.

- Strengthening the ability to participate in the reform of the security sector transformation of the civil society, professional associations, research institutions and advocacy.

- Striking a balance between arms purchase versus frontline military staffs' welfare and stabilizing society-military relations.

- Sifting through the different kinds of subsidies that are currently in place for members of the security forces and yet they do not benefit the poorly paid soldiers and police officers. For years Government has been subsidising the 
procurement of fuel, maize, wheat, soya bean and electricity among others benefiting both the poor and the rich.

Going forward, government should do away with all subsidies that only benefit the military officials and remain with those that are meant to protect vulnerable members of the uniformed forces. More crucially, there is a need for government to enhance domestic resource mobilization in order to improve the fiscal position of the country (for a more nuanced analysis of domestic resource mobilisation see (Moyo, 2020b)).

\section{Conclusion}

The article discussed the proposed garrison shops policy in Zimbabwe meant to benefit the members of the security services in purchasing subsidised groceries in barracks, cantonments and camps to cushion them from the rising cost of living. The article concludes that there is a need for improvements on security sector financial management, enhanced domestic resource mobilization, striking a balance between arms purchase versus frontline military staffs' welfare and stabilizing society-military relations. More importantly, the article motivates for the removal of all subsidies that tend to benefit the military hierarchies while the rank and file members of the security establishment live in penury. In putting together this think piece, the researchers faced data collection limitations as a result of COVID-19 lockdown measures which limited their access to a number of potential key informants who did not want to be interviewed digitally. However, the collected data was sufficient to produce the preliminary conclusions made in this article. Future researchers may consider looking into the defense budget against the welfare of frontline security forces in the context of the impact of the coronavirus crisis on the economy in Zimbabwe.

\section{Conflicts of Interest}

The authors declare no conflicts of interest regarding the publication of this paper.

\section{References}

Ali, H. E., \& Solarin, S. A. (2019). Military Spending, Corruption, and the Welfare Consequences. Defence and Peace Economics, 31, 677-691. https://doi.org/10.1080/10242694.2019.1567181

Auditor General Report (2018). Auditor General for the Financial Year Ended December 31, 2018 on State Enterprises and Parastatals. Presented to Parliament of Zimbabwe: 2019.

https://www.auditorgeneral.gov.zw/phocadownload/Parastatals/AG\%20PARA\%20REP ORT\%202018\%20June\%2020\%202019.pdf

Darboe, A. (2010). The Gambia: 1994-Present. https://www.nonviolent-conflict.org/gambia-1994-present/

Dwyer, M. (2016). Gambia: Why the Army May Be the Key to Getting Jammeh to Step Down.

https://africanarguments.org/2016/12/16/gambia-why-the-army-may-be-the-key-to-ge 
tting-jammeh-to-step-down/

Dwyer, M. (2017). Fragmented Forces: The Development of the Gambian Military. African Security Review, 26, 362-377. https://doi.org/10.1080/10246029.2017.1353530

Kairiza, T. (2020). Zimbabwe: Military in U.S. \$90 Million Murky Weapons Deals. https://www.theindependent.co.zw/2020/04/10/military-in-us90m-murky-weapons-deals/

Kells (2020). Soldiers, Police Receive Tripled Allowance While Other Sectors Get Less than a Fold.

https://www.zimetro.co.zw/soldiers-police-receive-tripled-allowance-while-other-secto rs-get-less-than-a-fold/

Leach, J. (2004). A Course in Public Economics. New York, NY: Cambridge University Press.

Mabhiza, L. (2020). ED Spoils Military Bosses with Expensive Flashy Cars. https://www.chronicles.co.zw

Matenga, M. (2020). Mnangagwa Spoils Soldiers, Police. https://www.newsday.co.zw/2020/08/mnangagwa-spoils-soldiers-police/

Moyo, G. (2016). The Curse of Military Commercialism in State Enterprises and Parastatals in Zimbabwe. Journal of Southern African Studies, 42, 351-364. http://www.tandfonline.com/action/journalInformation?journalCode $=$ cjss 20

Moyo, G. (2019). The Fetishised Role of External Actors in Zimbabwe's 2018 Elections: Implications for the Future, Plebiscites. Africana Studia, 141-157. https://ojs.letras.up.pt/index.php/1_Africana_2/article/viewFile/7019/6449

Moyo, G. (2020a). Obstacles and Opportunities for Financing the Fight against COVID-19 Pandemic in a Debt Trapped Zimbabwe. iBusiness, 12, 52-68.

https://www.researchgate.net/publication/342356779_Obstacles_and_Opportunities_for _Financing_the_Fight_against_Covid-19_in_the_Debt_Trapped_Zimbabwe

Moyo, G. (2020b). Domestic Resource Mobilisation and the Quest for Sustainable Alternative to External Debt in Zimbabwe. Zimcodd: Harare.

Moyo, G. and Phulu, K. (in Press). Weaponisation of COVID-19 in Zimbabwe: Legal and Extra-Legal Instruments.

Mugabe, T. (2020). Disaster: Hunger Hits Army Barracks, Soldiers Put on Forced Leave, Generals Slam Garrison Shops Idea.

https://www.myzimbabwe.co.zw/news/61078-disaster-hunger-hits-army-barracks-soldi ers-put-on-forced-leave-generals-slam-garrison-shops-idea.html

Ndebele, L. (2020). Zimbabwe's Zanu-PF Issues Warning to Opposition Leaders Ahead of Planned Protest.

https://www.sowetanlive.co.za/news/africa/2020-07-12-zimbabwes-zanu-pf-issues-war ning-to-opposition-leaders-ahead-of-planned-protest/

Rupiya, M. (2005). Civil-Military Relations in Zimbabwe: Is There a Threat? https://oldsite.issafrica.org/uploads/OURSELVESRUPIYA.PDF

Saungweme, R. (2020a). GVT Injects ZWL \$100 Million for GEMS Fund. https://www.hararepost.co.zw/en/the-news/local-news/3754-gvt-injects-zwl-100-millio n-for-gems-fund

Saungweme, R. (2020b). Joseph Jeu Selected Next DeCA Director. Defense Commissary Agency.

Trade Economics (2020). Zimbabwe's Inflation Rate. https://tradingeconomics.com/zimbabwe/inflation-cpi

Vinga, A. (2020). Ten Zim Soldiers Arrested for Armed Robbery. 
https://www.newzimbabwe.com/ten-zim-soldiers-arrested-for-armed-robbery/

World Bank Group (2019). Zimbabwe Overview.

https://www.worldbank.org/en/country/zimbabwe/overview

Zimbabwe National Statistical Agency (2019). Zimbabwe's Poverty Datum Line Tops $\$ 4.2 k$ in December 2019. https://www.ebusinessweekly.co.zw 